\title{
INFLUENCE OF DEM IN WATERSHED MANAGEMENT AS FLOOD ZONATION MAPPING
}

\author{
Muhamad Alrajhi, Mudasir-Khan, Mohammad Afroz Khan, Abdalla Alobeid \\ Dept. of Surveying and Mapping, Ministry of Municipal and Rural Affairs, Riyadh Olaya KSA- \\ alrajhi@momra.gov.sa
}

Commission VIII, WG VIII/1

KEY WORDS: GIS, DEM, Drainage Pattern, Flash-Floods, Hydrological Model, Stream Network, Flow Accumulation

\begin{abstract}
:
Despite of valuable efforts from working groups and research organizations towards flood hazard reduction through its program, still minimal diminution from these hazards has been realized. This is mainly due to the fact that with rapid increase in population and urbanization coupled with climate change, flood hazards are becoming increasingly catastrophic. Therefore there is a need to understand and access flood hazards and develop means to deal with it through proper preparations, and preventive measures. To achieve this aim, Geographical Information System (GIS), geospatial and hydrological models were used as tools to tackle with influence of flash floods in the Kingdom of Saudi Arabia due to existence of large valleys (Wadis) which is a matter of great concern. In this research paper, Digital Elevation Models (DEMs) of different resolution $(30 \mathrm{~m}, 20 \mathrm{~m}, 10 \mathrm{~m}$ and $5 \mathrm{~m})$ have been used, which have proven to be valuable tool for the topographic parameterization of hydrological models which are the basis for any flood modelling process. The DEM was used as input for performing spatial analysis and obtaining derivative products and delineate watershed characteristics of the study area using ArcGIS desktop and its Arc Hydro extension tools to check comparability of different elevation models for flood Zonation mapping. The derived drainage patterns have been overlaid over aerial imagery of study area, to check influence of greater amount of precipitation which can turn into massive destructions. The flow accumulation maps derived provide zones of highest accumulation and possible flow directions. This approach provide simplified means of predicting extent of inundation during flood events for emergency action especially for large areas because of large coverage area of the remotely sensed data.
\end{abstract}

\section{INTRODUCTION}

Most of the natural hazards result from potentially extreme geophysical events, such as floods, to create an unexpected threat to human life and property. When severe flash floods occur in areas occupied by humans mostly in low lying area or valleys (Wadis), they create natural disasters that involve greater loss of human life and property plus serious disruption to the ongoing activities of large urban and rural communities. Flood hazards results from a combination of physical exposure and human vulnerability reflected by key social-economic factors such as the number of people at risk in the flood plain or low-lying zone, the extent of flood, and the ability of the population to anticipate and cope up with hazard.

The Wadis or valleys act as natural bowl (container) which on receiving right amount of precipitation gets filled up, resulting in sudden runoff of water in the form of streams causing flash floods, which directly affect the sustainability of concerned area or region. Catastrophic flash floods occurring in Wadis on one hand, a threat to many communities and on the other hand, major groundwater recharge source after storms.

The topography of the Kingdom of Saudi Arabia supports existence of large Wadis naturally, also with rapid developments and changing basement conditions increase chances at rapid speed. The water accumulating from precipitation did not percolate down directly, due to altered ground conditions. Such conditions were responsible for the flash floods of Jeddah during the past.
Thus DEM acts as a basic digital data set, necessary to perform hydrological modelling in Wadi systems. Several characteristics about the surface hydrology of a particular area can be determined using DEM. Processing DEM data to extract hydrological features has become common procedure (Garbrecht and Martz, 1996). Hydrological applications of digital elevation models have recently become an important factor in determining the runoff response to rainfall is topography. Spatially hydrological modeling takes this factor into account through the use of DEM. Many sources of data can be used for producing DEM of the region: Field survey, topographic maps, aerial photographs and satellite images.

Modeling relief, as one of the most determinant elements of landscape components has become essential in environmental research (Mezősi and Bódis 1999). Escalating hydrological problems (extreme events, floods, droughts, managing water-resources, soil erosion, environmental effects of climate change) and the development of mathematical modeling techniques involving digital (spatial) data processing and analyses, GIS (geographical information systems) and RS (remote sensing) technologies have also opened up new prospects to hydrological modeling (Beven and Moore (Eds.) 1995; Bates and Lane (Eds.) 2000; Grayson and Blöschl (Eds.)2000; Beven 2001). These developments have enabled the spatial discretization of hydrological processes, and the resulting models are called distributed models. The principle of distributed modelling is that the analysis of sub-processes is done by dividing the area under investigation into elements (cells, grids), within which the processes are represented. Among the most important components, there are the terrain and its derivatives. Thus cell-based digital elevation modelling and applications in hydrological modelling is targeted by several research activities. 
The interpolation technique and grid size of the DEM can also vary. Geographic Information Systems (GIS) algorithms allow the user to combine different topographical data layers to build a single DEM. The accuracy of these different DEMs is extremely variable. As DEM errors propagate through the hydrological model so, the accuracy of the simulated hydrographs is strongly related to the accuracy of the DEM used (Lagacherie, et.al., 1996).Digital elevation models are used to delineate river networks and watersheds to investigate areas which are directly under the influence of runoff water.

\section{STUDY AREA}

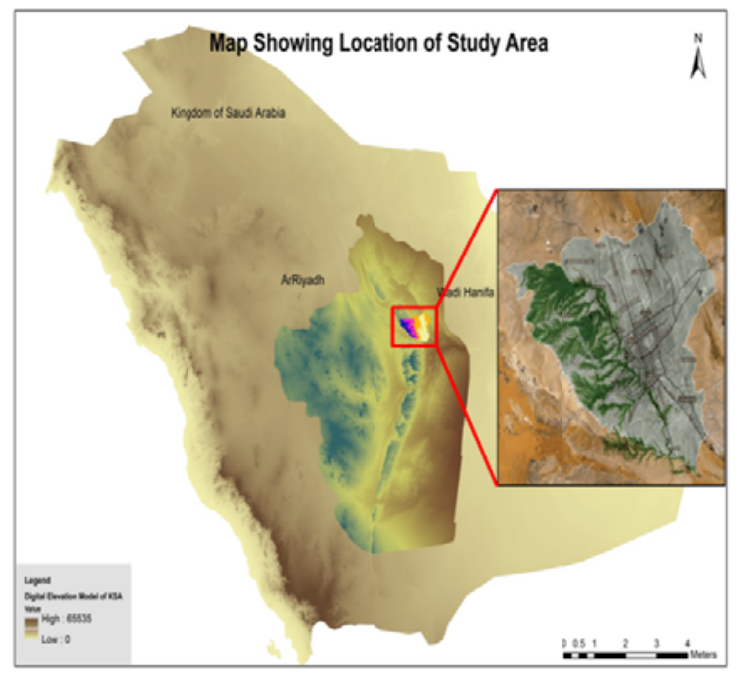

Figure 1. Shows Imagery of Wadi Hanifa in Riyadh - KSA

Located in the middle of Najd Plateau in the Kingdom of Saudi Arabia, the Wadi Hanifa watershed is the most significant natural landmark in the region as shown in (Figure 1). Its basin and many tributaries form a unique 120 kilometer-long ecological zone that descends from the Tuwaiq escarpment in the northwest to open desert southeast of Riyadh. The development of the wadi (referring henceforth to the wetlands) is inextricably tied to the history of Riyadh.

An oasis at the heart of the Arabian Peninsula, the Wadi Hanifa watershed system has long provided sustenance for communities along its length. For centuries a balance prevailed between the water, land and resources of the wadi and the people living around it, between natural processes and human interventions. This stability existed because the inhabitants of the wadi were completely dependent on it for their survival and prosperity.

The first Saudi state strategically located its capital at Addiriyyah city on the west bank of Wadi Hanifa, taking advantage of water, stone, and arable lands. Subsequently, Riyadh or Arriyadh city, the new capital of the modern Saudi state, developed to the east of Wadi Hanifa. Until the rapid expansion of Riyadh that started in the mid-1970s, the city and the wadi existed in harmony with each other, with the wadi used as a sustainable resource for water and food.

\subsection{Wadi System Characteristics}

In arid regions, water is one of the most challenging current and future natural-resources issues. The arid and semi-arid regions of the world are characterized by the expanding populations, increasing per-capita water use, and limited water resources as well as draught and flash flood threats.

\subsection{The Target Watershed Basins}

Due to aforementioned characteristics and problems of Wadi system in the arid and semi-arid regions, Wadi Hanifa catchment area in Riyadh has been selected from Saudi Arabia, due to the importance not only as water resource but also as flash flood and drought threat. In other words, due to the direct and major impact of Wadi system on security of life of urban and rural population in the kingdom.

\section{OBJECTIVES}

1. Comparative analysis of flow accumulation network based on different resolutions of DEM

2. Comparability of derived river profile based on different resolutions of DEM

3. Overlay operation of derived stream network from different resolutions of DEM on GeoEye $(.5 \mathrm{~m})$ satellite imagery to check the exact matching of stream flow

4. Evaluation of Standard deviation error for elevation values obtained from different resolutions of DEM

5. To present the applicability of elevation models and derived spatial information using GIS operations in hydrological modelling for decision support, addressing the theoretical support for strategic and operative flood prevention, making the presented modelling technique an integral part of flood zonation mapping.

\section{METHODOLOGY}

The current study was carried out for Wadi Hanifa in Riyadh and designated to investigate influence of (DEM) in watershed management as flood zonation mapping shown in (Figure 2) and determine inundated areas during high precipitation for decision and planning. To achieve the aforementioned objectives, the following methods were adopted: Digital Elevation Model (DEM) ASTER-30m, from USGS and $(20 \mathrm{~m}, 10 \mathrm{~m}$, and $5 \mathrm{~m})$ were generated from topographical data of $(1: 1,000)$ scale map from Ministry of Municipal and Rural Affairs (MOMRA), Satellite Imagery GeoEye-1 $(0.5 \mathrm{~m})$ resolution from (MOMRA) which have been extensively used and analyzed in ESRI ArcGIS software to generate sets of digital maps for the study area. Generated maps from digital elevation model include: drainage pattern or stream network, flow accumulation, flow direction, and flood hazard map. 


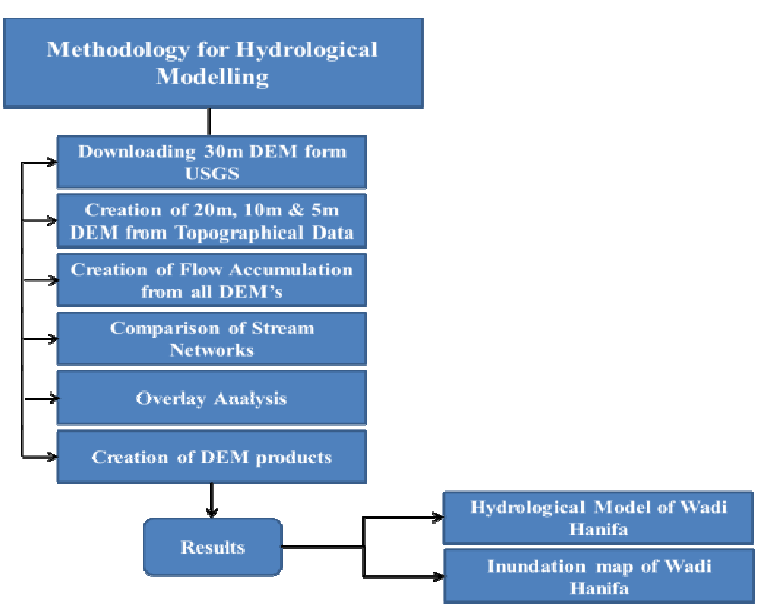

Figure 2. Showing Methodology for Hydrological Modelling.

Tremendous growth in the telecommunication and engineering industries has created a greater demand for terrain data. This data will allow engineers to plan and manage all infrastructure growth with the necessary required by new spatial applications. Other primary applications include mobile communications, terrain visualization, cartographic analysis, slope analysis, and environmental modelling. DEM's areas used often in geographic information systems, and are the most common basis for digitally produced relief maps as shown in Figure 3.

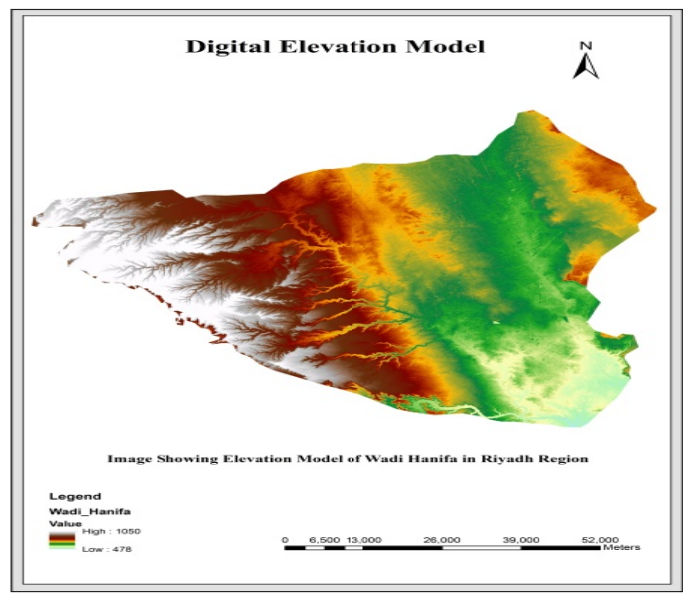

Figure 3. Showing DEM of the Study Area.

\subsection{Hydrological Modeling}

The $30 \mathrm{~m}$ resolution DEM obtained from (USGS) and generated DEM's of $(20 \mathrm{~m}, 10 \mathrm{~m}$, and $5 \mathrm{~m})$ resolutions has been subjected to various hydrological analysis to study the direction of flow and flow accumulation in order to carry out comparability analysis between stream networks derived from different elevation models of different resolutions based on flow accumulation maps as shown in Figure 4.

The same approach is used to derive other products from elevation models which include, flow direction, flow accumulation and flood hazard maps with stream networks which has been overlaid on $(0.5 \mathrm{~m})$ GeoEye- 1 , satellite image for mitigation of inundated areas during high precipitation.

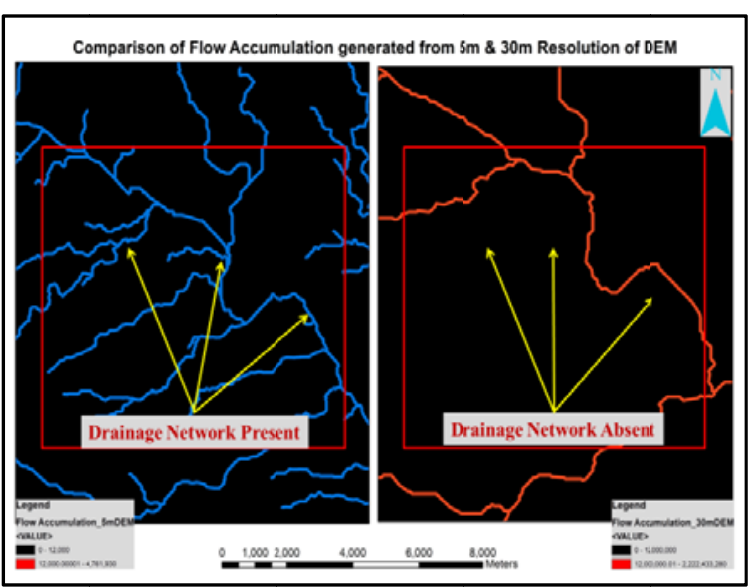

Figure 4. Showing Comparison of Flow Accumulation of the Study Area.

\subsection{Drainage pattern}

The drainage map of an area is a useful tool to test the lineaments in the area. The movement of water over land surfaces is an important feature governed primarily by terrain shape. The terrain shape, on the other hand, is a result of all internal and external factors that collectively shape the area. Therefore, certain characteristic drainage patterns and sudden changes in flow direction can be attributed to the fractures that are recognizable on the satellite image. Drainage network extracted from DEM using different thresholds are shown in Figure 5.

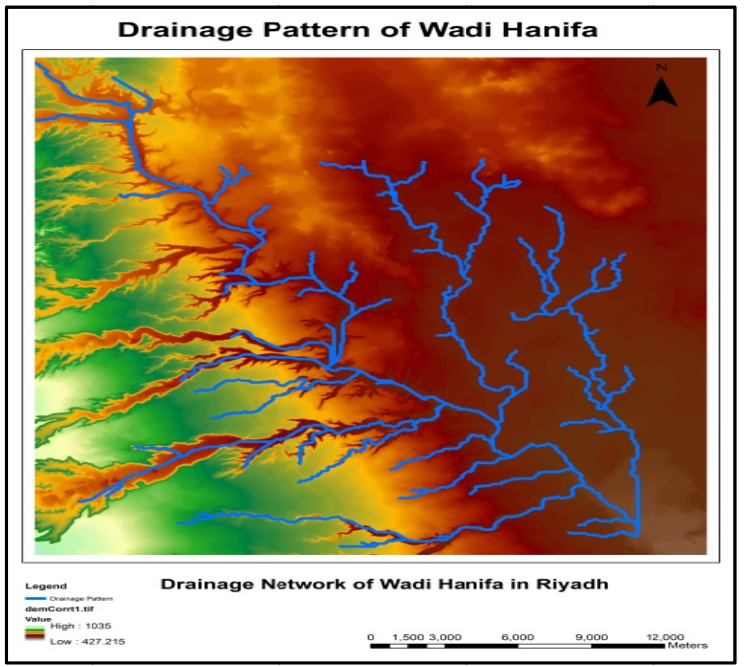

Figure 5. Showing Drainage pattern of the study area.

Assessing drainage systems in the context of surface deformation is getting very important because they represent the witnessing of erosive and tectonic processes which may have disconnected, linearized and changed the dendritic behavior of drainage system. The morphology of the drainage network is clearly influenced by geological forces at 
different stages. The study area features mainly two types of spatially distributed drainage patterns: major stream course changes (dendritic) and straight stream lines.

The straight stream line patterns consist of a sudden change in the stream orientation due to geotectonic conditions or mainly due to human interventions. The straight stream line patterns can be easily recognized from satellite images. The water channels thus flow through the valleys between ridges and spurs resulting in a pattern that resembles a tree and its branches. Dendritic patterns, with channels oriented in wide variety of directions, are common place in areas of nil or very slight slope, and little or no structural influence.

\subsection{Comparability of River Profiles}

The river network obtained for Wadi Hanifa basin has been operated for various processes to derive flow direction maps, which results flow accumulation maps to delineate those areas which receive highest precipitation and represent those channels where runoff flow is more.

These high flow zones form channels and delineate network system of wadis. The water always flows from higher reaches to downwardsin different network systems like dendritic, radial and rectangular, but the current study area is dominated by dendritic pattern of stream network where the water is mostly coming from higher reaches feeding main channel in meandering pattern in low-lying areas of the wadi.

The comparability of main river channel was carried out based on the drainage network obtained from different resolutions of DEM, to check the course of derived river. The studies reveal that high resolution DEM provide exact flow course of river as shown in Figure 6a, which delineates flow of a river with changing elevations and provides greater details about the river meandering, while as the resolution of DEM changes it shows lesser river meandering as show in Figure $6 \mathrm{~b}$. The river profile obtained for $30 \mathrm{~m}$ resolution DEM shows a smooth downward movement of river course without much curves with changing elevations of the Terrain as shown in Figure 6c. The stream network derived from different resolution DEM is compared based on elevations calculated and stream length in order to delineate 3D profile graph for visual interpretation as shown in Figure 6d.

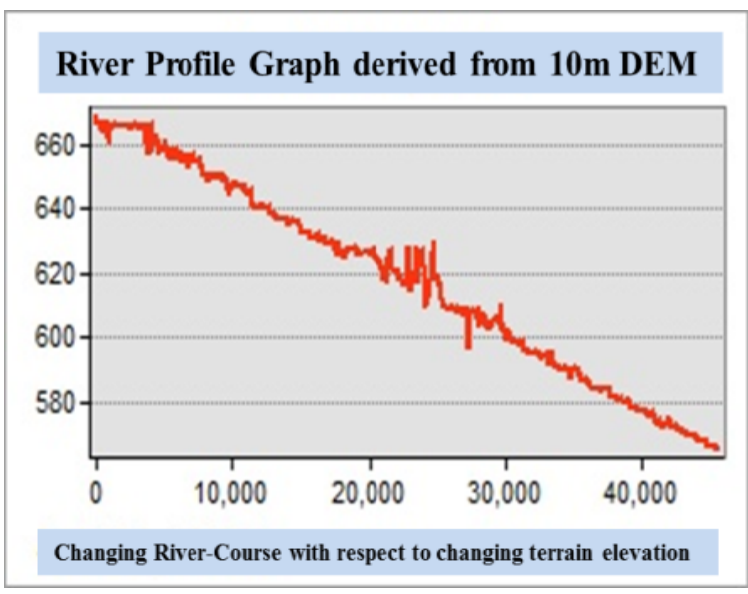

Figure 6a. Showing River Profile Graph derived from 10m DEM.

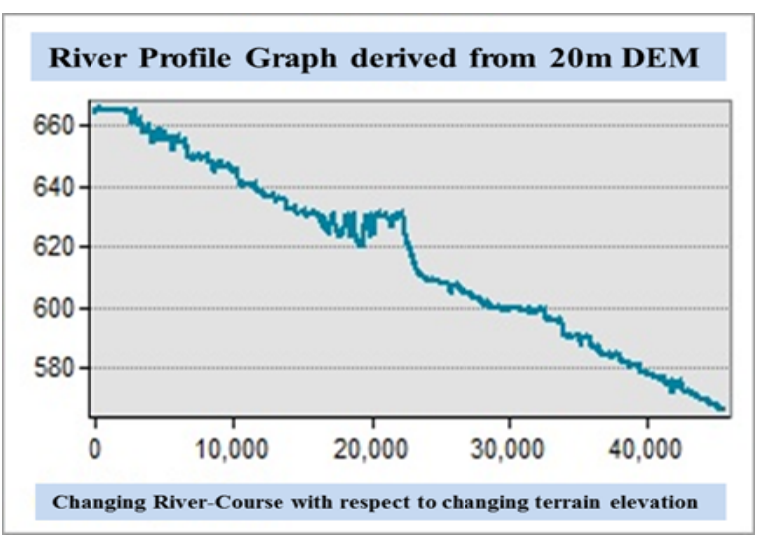

Figure $6 \mathrm{~b}$. Showing River Profile Graph derived from $20 \mathrm{~m}$ DEM.

River Profile Graph derived from 30m DEM

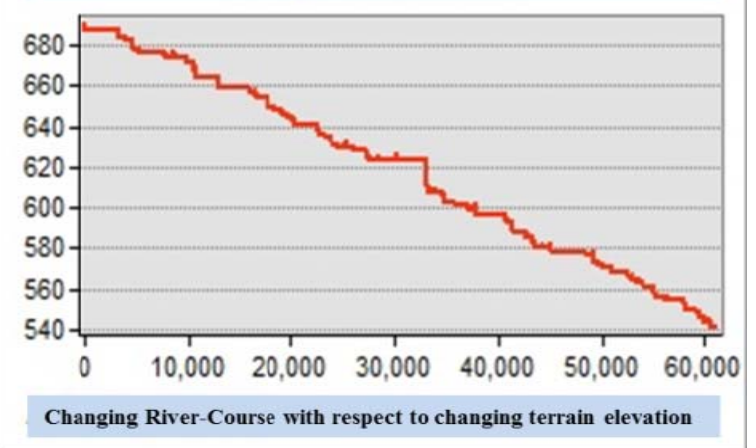

Figure 6c. Showing River Profile Graph derived from 30m DEM.

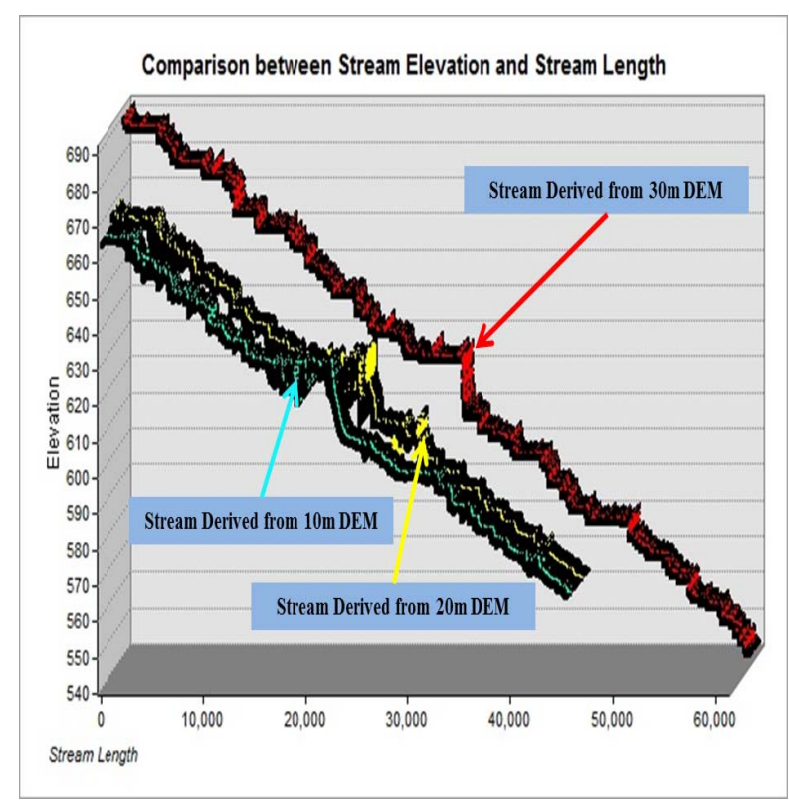

Figure 6d. Showing comparison of stream elevation and stream length based on different DEM. 


\subsection{Overlay Analysis}

The drainage network obtained from Digital Elevation Model was overlaid on Satellite image GeoEye-1 $(0.5 \mathrm{~m})$ resolution to check the extent of overlapping between the imagery and derived drainage network and also to interpret the course of stream network flowing through main and subsidiary channels. The derived stream network from $5 \mathrm{~m}$ Digital Elevation Model (DEM) shows almost exact overlapping of main and subsidiary channels which feed the main stream body as shown in Figure 7a.

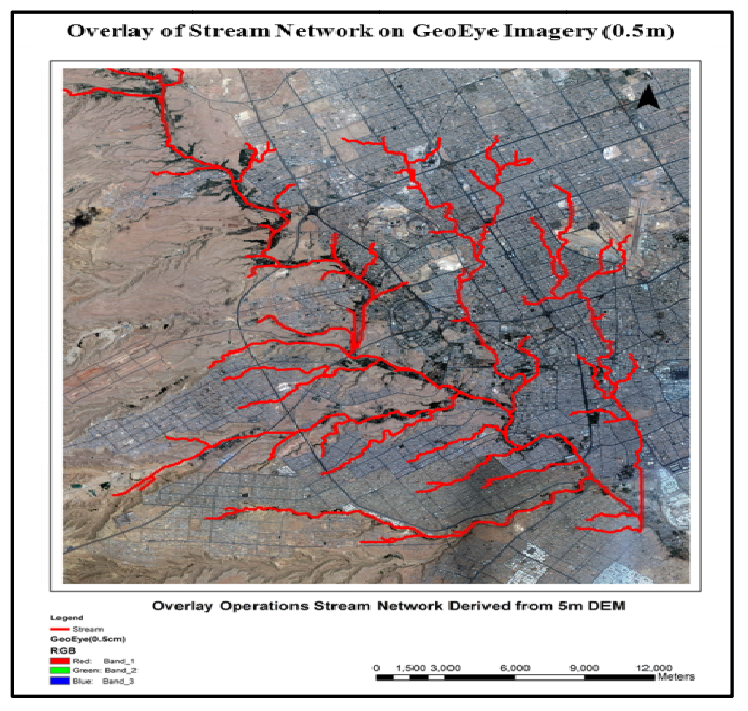

Figure 7a. Showing overlaid stream network derived from $5 \mathrm{~m}$ DEM on GeoEye $(0.5 \mathrm{~m})$.

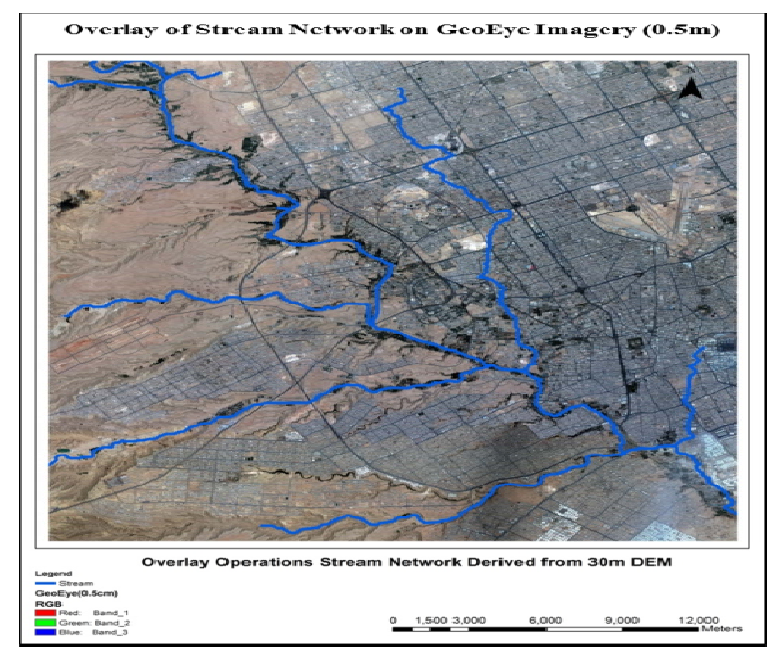

Figure $7 \mathrm{~b}$.Showing overlaid stream network derived from $30 \mathrm{~m}$ DEM on GeoEye $(0.5 \mathrm{~m})$.

The results obtained for overlapping operations in case of stream network derived from 30m DEM show a greater loss of densified network, which only delineates course of river but not with dense details of feeding subsidiary channels which overlap in case of stream network derived from $5 \mathrm{~m}$ DEM as shown in Figure $7 b$.
4.5 Evaluation of Standard deviation errors for elevation values obtained from different resolutions of DEM

The elevation values of known spot points for the wadi Hanifa have been taken as reference for comparative analysis to check and evaluate the amount of deviation of results from reference values. The spot height data has been taken from Ministry of Municipal and Rural Affairs (MOMRA) 1:1,000 scale topographic line mapping data as shown in Figure 8.

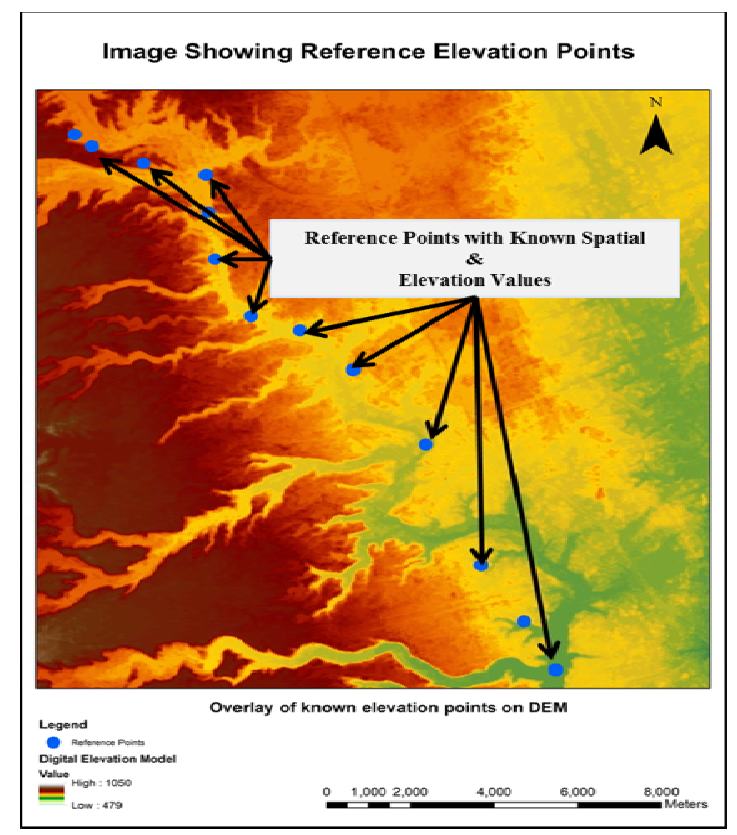

Figure 8. Showing overlaid reference elevation points on DEM

The number of selected reference points for conducting comparative analysis based on different elevation models has been taken along the course of main channel in wadiHanifa. The spatial $(\mathrm{x}, \mathrm{y})$ and elevation values $(\mathrm{z})$ for the study area are shown in Table 1.

\begin{tabular}{|c|c|c|l|}
\hline \multirow{2}{*}{ FID } & \multicolumn{4}{|c|}{ Reference elevation from spot hei ghts 1K } \\
\cline { 2 - 4 } & X Values & Y Vahes & Z Values \\
\hline 1 & 651305.027 & 2745138.597 & 726.8603 \\
\hline 2 & 651703.618 & 2744796.162 & 677.1143 \\
3 & 652943.535 & 2744308.834 & 698.3872 \\
4 & 655507.378 & 2739832.357 & 661.3475 \\
\hline 5 & 661002.492 & 2732566.555 & 656.15 \\
\hline 6 & 662025.485 & 2730929.268 & 624.6688 \\
\hline 7 & 659686.593 & 2736089.332 & 645.138 \\
8 & 662558.541 & 2728145.922 & 615.4464 \\
9 & 663396.296 & 2727582.777 & 614.2886 \\
10 & 664175.834 & 2727161.847 & 611.0857 \\
\hline 11 & 657954.477 & 2738280.78 & 668.8479 \\
\hline 12 & 667721.792 & 2725332.322 & 597.6371 \\
\hline
\end{tabular}

Table1. Showing the spatial and elevation values for reference points 
The comparative results obtained for different resolution of DEM and reference points show that $5 \mathrm{~m}$ (DEM) shows less deviation than followed by $10 \mathrm{~m}, 20 \mathrm{~m}$ and $30 \mathrm{~m}$ (DEM) in a sequence. The results obtained delineate that $30 \mathrm{~m}$ (DEM) has more errors than $5 \mathrm{~m}$ resolution of DEM. The standard deviation values can be seen in Table 2 .

\begin{tabular}{|c|c|c|c|c|}
\hline FID & $5 \mathrm{~m}$ Elev & $10 \mathrm{~m}$ Eles & $20 \mathrm{~m}$ Eley & 30m_Elev \\
\hline 1 & 7.302407 & 7.302403 & 7.495952 & -3.269927 \\
\hline 2 & 0.219832 & -0.384842 & -1.25479 & -24.63292 \\
\hline 3 & 7.667248 & 7.667262 & 7.446471 & -16.91312 \\
\hline 4 & 1.685119 & 1.700774 & 1.686521 & -5.051938 \\
\hline 5 & 4.047149 & 4.04717 & 4.04715 & -6.470353 \\
\hline 6 & 0.490381 & -3.773522 & -6.850975 & -11.76353 \\
\hline 7 & 2.436078 & 2.436058 & 2.439728 & -3.419504 \\
\hline 8 & 0.030065 & -12.99592 & -16.07337 & -7.5536 \\
\hline 9 & 0.165412 & 0.175526 & 0.202434 & -6.032235 \\
\hline 10 & 2.826337 & 1.74433 & 0.001288 & 1.568505 \\
\hline 11 & 0.883816 & 0.883797 & 0.883795 & -9.613384 \\
\hline 12 & 1.700556 & 1.679329 & 1.696964 & 1.6371 \\
\hline Std.Dev & 2.64484 & 5.377717 & 6.375621 & 7.471615 \\
\hline
\end{tabular}

Table2. Showing standard deviation of elevation values computed from different resolutions of DEM

The standard deviation graph derived from compared values shows a smooth and positive trend for computed elevation values for $5 \mathrm{~m}$ (DEM) and become courser as the resolution increases. The standard deviation graph for the computed values is shown in Figure 9.

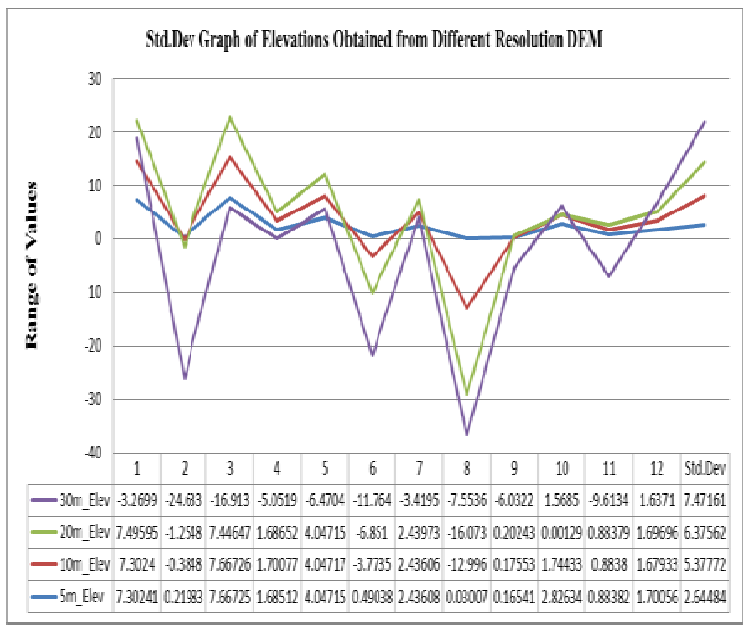

Figure 9. Showing standard deviation graph for compared values

\subsection{Flood Hazard Map for Wadi Hanifa}

The flood hazard map provides information about high reach areas and low lying plains mostly concentrated by population, which are altering the Wadi basement directly or indirectly either by construction or by dumping wastes in low lying areas, which possibly have adverse effects because both cases decrease infiltration capacity of river and results in flooding like situations. Also due to significant expansion and in the city and commercial activity affected the Wadi badly. Quarrying for stone and extractions of soil for construction work undercut the banks of the flood channel as shown in Figure 10. There was unregulated mineral mining, data palm plantations flanking the Wadi encroached in flow channel, which further impeded by uncontrolled dumping. As a result, the seasonal flash floods caused unnecessary erosion and swept pollutants into residential neighborhoods. Stagnant water jeopardized public health.

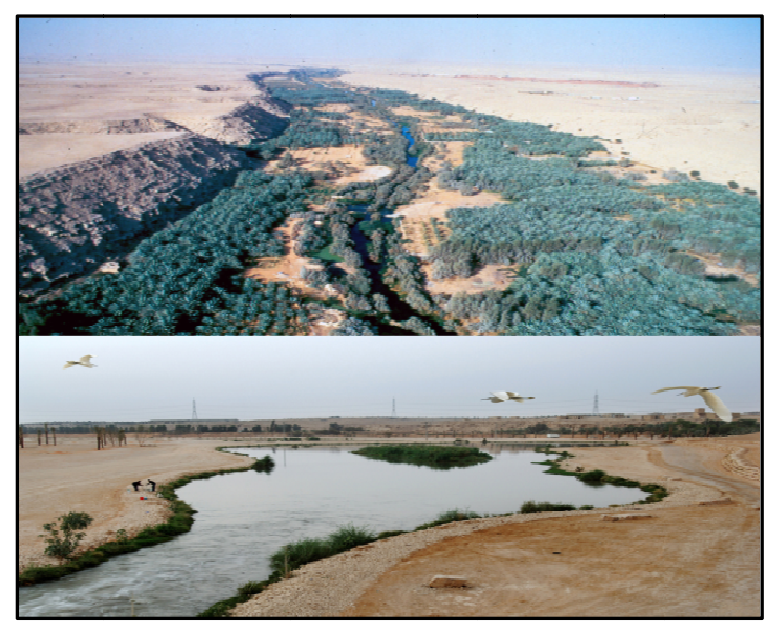

Figure 10. Showing undercut banks of flood channel in Wadi Hanifa.

From the deduced drainage pattern the scenario for the expected flooding directions can be easily estimated as shown in Figure 11. In general there are two distinctive directions for the rainfall water, one towards the northwest and other towards southeast directions.

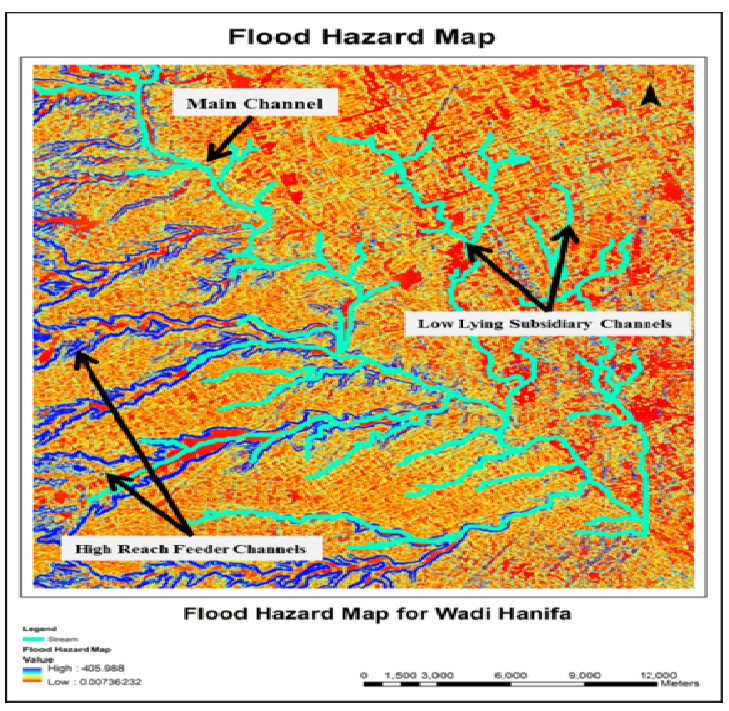

Figure 11.Showing flood hazard map for Wadi Hanifa.

The comparative results of DEM and its relevant derived morphometric features and drainage pattern make it possible to easily interpret the basin with upper and low-lying areas, which are possibly dangerous during flash flooding event. 
Also more investigations for Wadi-Hanifa show that drainage pattern is helpful in determining the directions of running water and the possible locations where it accumulates. The flow accumulation maps derived from high resolution DEM provide the highest possible areas which receive precipitations and can help to mitigate its directions also.

\subsection{Flood Control in the Desert}

Riyadh receives an average of 100 millimeters (4") of rain each year, that's not much but it tends to come in the form of sudden downpours. Only 10 days per year on average have rain and nearly all come between January and April.

Across the Najd desert that surrounds Riyadh, these rains flow naturally into Wadis. Since the Najd tilts from the high ground northwest of Riyadh south and east toward the Gulf coast, all of Najd's small wadis feed their runoff water into one major artery: Wadi Hanifah. This means that by the time waters reach the edge of Riyadh, they often swelled into potentially destructive flash floods.

\section{RESULTS AND DISCUSSIONS}

Digital Elevation Models play a very important role for watershed management because the surface water features and storm-water runoff within a watershed ultimately drain into other bodies of water. It is essential to consider these downstream impacts when developing and implementing water quality protection and restoration actions. Everything upstream ends up downstream. We need to remember that we all live downstream and that our everyday activities can affect downstream waters.

The flow accumulation networks obtained clearly depicts those areas which are directly at risk during high precipitation conditions and provides zones of high accumulations where water seeps down quickly and simultaneously delineating run-off water.

The inundation map obtained from DEM also provide major change of elevations and maximum approximation for flooding extend during high precipitation, thus inundation maps plays a crucial role in helping decision-makers to take appropriate measures that alleviate and reduce the adverse impact of floods.

No doubt the study provides broader spectrum about the hydrology of the Wadi Hanifa but simultaneously the study visualizes us about the natural disasters which surrounds the Wadi. During high or even in moderate precipitation, water will move directly towards low-lying areas as run-off. The run-off water will directly influence lower reaches as the water absorbing capacity of soil is less due to changing basement and will remain continuously changing with human interventions. The state of architecture is constantly changing due to which the basement of the terrain is also getting altered, which affect the water holding capacity of the underground surface, due to which the water remains localized in the upper surface and results in flood like situations. Thus, current study provides us informative approaches for influence of DEM in watershed management for flood zonation mapping by watershed management modelling and assessment by generating inundation maps.

\section{CONCLUSION}

Digital Elevation Models play a crucial role for determining hydrological system of Wadis and secondly acts as a key feature in defining flow channels in Wadis for water management and provide clear view about main stream channel, in order to engineer grading and channeling, to control its flow and minimize the destructive effects of floods.

\section{ACKNOWLEDGMENTS}

The authors would like to extend their sincere appreciation to the Ministry of Municipal and Rural Affairs for support of this research.

\section{REFERENCES}

Azizian, A. \& Shokoohi, A. 2015. "Investigation of the Effects of DEM Creation Methods on the Performance of a Semi distributed Model: TOPMODEL." J. Hydrol. Eng., 10.1061/(ASCE)HE.1943-5584.0001204, 05015005

Bates, P.D., Lane, S.N. (Eds.) 2000.High Resolution Flow Modelling in Hydrology and Geomorphology, John Wiley \& Sons, 2000.p. 374.

Beven, K. J., Moore, I. D. Eds.1995.Terrain analysis and distributed modelling in hydrology (Advances in Hydrological Processes), John Wiley \& Sons, p. 249.

Beven, K.J., 2001. Rainfall-Runoff Modelling: The Primer, John Wiley \& Sons Inc p. 372ISBN: 0-471-98533-8, Chapter 3 Data for Rainfall-Runoff Modelling

Bódis,K.,(1999).Geometriai transzformációk,transzformációsegyenletekésalkalmazásuka geoinformatikában Applications of geometrical transformations in GIS science, Diplomathesis, Szeged p. 52.

Eric K Forkuo., 2013, the use of Digital elevation models for watershed and flood hazard mapping, Department of Geomatic Engineering Kwame Nkrumah University of Science \& Technology Kumasi, Ghana pp.56-65.

Garbrecht, J., and Martz, L. W., 1996, Digital landscape parameterization for hydrological applications. In Hydro GIS 96: Applications of Geographic Information Systems in Hydrology and Water Resources Management (Proceedings of the Vienna Conference, April 1996), IAHS Publication no. 235 .

Grayson, R., Blöschl Eds. 2000. Spatial patterns in Catchment Hydrology: Observations andmodelling, Cambridge University Press, 2000 ISBN 0-521-63316-8

Janet Nichol., Law K. H, 2008. The influence of DEM accuracy on topographic correction of IKONOS satellite images, Publication PERS vol.74, No.1, pp,47-53

KatalinBodis, 2008. Digital elevation model and their applications in flood risk management. Doctoral, $\mathrm{PhD}$. 
Thesis, Department of physical Geography and Geoinformatics.

Kevin J. McGuire., JeffreyJ.McDonnell., 2006. A review and evaluation of catchment transit time modeling. Vol.330, issues 3-4, pp543-563.

Langacherie, et. al., 1996. Effects of DEM data source and sampling pattern on topographical parameters and on a topography based hydrological modelHydro GIS 96: Application of Geographic Information Systems in Hydrology and Water Resources Management (Proceedings of the Vienna Conference, April 1996). IAHS Publ. no. 235, 1996

Longley, P.A., Goodchild, M. F., Maguire, D.J., Rhind, D.W. (Eds.) (1999): Geographical Information Systems, Volume I. Principles and Technical Issues, Volume II. Management Issues and Applications, 2nd edition, Wiley, New York15

M.Saber.,T.Hamaguchi.,T.Kojiri.,K.Tanaka.2009.

Spatiotemporal runoff features of hydrological modelling in Arabian wadi basins through comparative studies, annuals of Disas.Prev.Res.Inst.,Kyto Univ., No. 52B, 2009

Matthew Teller., 2012. Report on Arab and Islamic cultures and connections

Maune, D.F, Editor 2007. Digital Elevation Model Technologies and Applications: TheDEM User's Manual, (2nd Edition), AsprsPubns, p. 620, ISBN 1-57083-082-7

Mezősi, G., Bódis, K. 1999. Statistical Evaluation of Landscape Units, In: Kovar, P.Editor, 1999, Nature and culture in landscape ecology. Karolium, Prague, pp. 170-183.

Moore, I. D., Grayson, R. B. and Ladson, A. R. 1991. Digital terrain modelling: A review of hydrological, geomorphological, and biological applications, Hydrological Processes, Volume5 Issue 1, pp. 3 - 30. and In: Beven, K. J., Moore, I. D. (Eds.), 1995, Terrain analysis and distributed modelling in hydrology (Advances in Hydrological Processes), John Wiley \&Sons,pp. 7-34.

Olaniyan, O.S,,Akolade, A.S., 2015. Flood Plain Determination using geographical information system (GIS) IJEER Publication vol.3, No.2, pp.22-36

W.A.Samhori., M.A.Naim. 2007. Wadi Hanifa wetlands on site review report by Arriyadh Development Authority. 